\title{
Ethno-Religious Conflicts in Nigeria: Implications on Women
}

\author{
Nkechi G. Onah \\ Ph.D., Department of Religion and Cultural Studies \\ University of Nigeria, Nsukka \\ Benjamin C. Diara \\ Ph.D., Department of Religion and Cultural Studies \\ University of Nigeria, Nsukka \\ Favour C. Uroko \\ Department of Religion and Cultural Studies \\ University of Nigeria, Nsukka
}

Doi: $10.2478 / \mathrm{mjss}-2018-0097$

\section{Abstract}

Ethno-Religious conflicts have continued to besiege Nigeria for decades. This paper aims to highlight some of the ethno-religious conflicts that have taken place in Nigeria and its impact on women. Considerable work has been done on the issue of Ethno-Religious conflicts in Nigeria but the implications of these on Nigerian women remains scanty. It is in recognition of this that this paper seeks to examine this. Using library findings as well as oral interviews, the paper notes that many women have lost their lives while many others have lost their children and/or their husbands. This situation has led to undue sufferings with the concomitant problems of poverty and penury among the women. Most significantly, it also leads to gender inequality. Gender inequality translates to political, economic and socio-religious marginalization of women in the society. In view of this, the researcher recommends among others that women should be allowed to be full actors in the process of peace building and conflict resolution in Nigeria. They should not be kept at the margin in political discourse. It further advocates that amidst these incessant ethno-religious conflicts that have plagued the nation, protection of women and children should be of paramount importance and all the violations of human rights of women and children addressed with the apt attention it deserves. The decriptive phenomenological method was adopted for the study.

Keywords: Nigeria, Ethno-Religious Conflicts, women, girls, Human rights abuse, gender

\section{Introduction}

For several decades now, Nigeria has been witnessing an upsurge in ethno-religious conflicts. Nigeria is a country of diverse and rich cultural heritage. With a population of over 178.5 million people (World population review 2016), Nigeria remains the most populous nation in Africa endowed with rich natural resources. Despite this, Nigeria is faced with many problems and challenges among which ethno-religious conflicts seems to top the list. Ethno-religious conflicts have created instability and remained a constant threat to peaceful co-existence in the Nigeria society.

Nigeria's multi-ethnic and multi-religious diversities coincide with the North and South divide, 
with Muslims and Christians dominating each part respectively. These have created geo-religious identities; a situation where religion and its concomitant tension generation enthroned a threat to security of the country (Ukandu 2011). However, with her three dominant religions; African traditional religion, Islam and Christianity, it may be necessary to observe that irrespective of the seeming divide; indigenous Christians are in large numbers all over the northern states (Yakubu and Rothfuss, 2012). They further explained that Christians are in majority in at least seven out of the nineteen northern states while north-western and north-eastern regions have the largest concentration of Muslims. The North-central also known as the Middle Belt, is considerably mixed with a Christian majority. Indigenous Muslims are in large numbers in south-western states and are in small minority in the south-south while practitioners of African traditional religion can be found all over the country. Some are syncretistic, combining Islam or Christianity with traditional religion (Yakubu and Rothfuss, 2012). In the South East Christianity dominates. One would think that the presence of these religions would foster peaceful co-existence and unity in a multi-ethnic and multilinguistic society like Nigeria but multi-religiosity has tended to impact negatively on the nation creating tension and unrest. This made Dukor (1988:61) to assert that:

....religion is not a concept which is intrinsically bad. It is rather an integrating force. Religion as a disintegrating force is attributable to the organizers, the organization, the preachers, the preaching, the propagators and the propagation of religions.

As Jega (2002: 22) observed "Socio-ethnic conflicts are deflected and fought under interreligious banner. This is because there is a strong overlap between ethnic and religious boundary in Nigeria's plural setting". Lending credence to the above, Adejo (2002:248) stated that "each conflict does not just happen..., they are rooted in some basic dissatisfaction or grievances which await detonation at the slightest opportunity". This has led to suspicion and unhealthy rivalry among the diverse ethnic groups including adherents of Islam and Christianity.

Judging by incidence of religious conflict, the northern region has become the hotbed of religious extremism (Yakubu and Rothfuss, 2012) making people scamper for safety and turning many into refuges in their own country. The recent upsurge of Boko Haram Islamic fundamentalism, which detests western education and Christianity, has exacerbated the conflicts already in existence. Thus, the religio-political history of Nigeria is characterized by unprecedented upsurge in ethnic and religious conflicts leading to loss of lives and destruction of properties worth billions of Naira. This paper therefore, is based on the premise that ethno-religious conflicts have remained recurrent decimals in Nigeria. Against this background, this paper examines some ethno-religious conflicts that have taken place in Nigeria with particular interest on the implications of these conflicts on women. Thus, the aim of this paper is to bring to fore front the plight of Nigerian women in the face of incessant ethno-religious conflicts going on in Nigeria. It will further attempt to proffer solutions on ways of ameliorating the impact of these conflicts on women.

\section{Research Methodology}

Data for the study were generated from textbooks, journals, newspapers, magazines and publications on the web. Additional information was elicited through in-depth interviews among some women who are victims of ethno-religious conflicts. The aim was to evaluate the implication of these conflicts on the lives of Nigerian women for necessary intervention. The data collected were qualitatively and critically analyzed. The descriptive phenomenological method was used in this research.

\section{Colonialism and the Origin of Ethno-Religious Conflicts in Nigeria}

Literature abounds on causes of ethno-religious conflicts in Nigeria. However, our concern here is on the activities of the Colonial masters that laid the foundation of ethno-religious conflicts in Nigeria. The British colonial masters have been blamed for the ethnic and religious conflicts in Nigeria. For instance, Uchendu (2010) observed that the growth of ethno-religious intolerance in the 
country has its foundation on the activities of the colonial masters that brought Christianity with them and antagonized African Traditional Religion as idolatry.

Christianity was first introduced at Benin in the fifteenth century by Portuguese Roman Catholic priests who accompanied traders and officials to the West African coast. But no significant success was made. Significant missionary activity was renewed only in the 1840s (http://www.mongabay.com/history/nigeria/nigeria-influence_of the_christian_missions.html). The first batch of Christian missionaries arrived Badagry in $\overline{1842}$, from there Christianity spread to Abeokuta and other parts of the hinterland (Yusuf and Osoba 2010).

Prior to the advent of Colonialism, Islam was introduced to northern region in eleventh century and by the sixteen century it had made headway in major capitals of the region, extending to the country-side and toward the middle belt uplands. Shehu Usman dan Fodio established a government based on Islam in Northern Nigeria before Colonialism took place (Onimhawo and Ottuh, 2010:89).

Tracing the history of the background of ethno-religious conflicts in Nigeria, Uka (2008) avers that Nigeria, before it was colonized by the British, had a multi-cultural/multi-ethnic, multi-lingual and even multi-political culture and was extremely heterogeneous and complex. In related analysis, (Ofoeze 2009:181), remarks that:

\begin{abstract}
Nigeria... is a multi-ethnic plural society with the Igbo, Hausa and Yoruba consisting the three largest groups. Each of these ethnic groups, prior to colonial invasion had existed independently on its own and had its own socio-cultural, political and economic systems by which the entire life of its members was organized. These systems varied quite markedly among these ethnic groups so much so that in some cases, they were mutually antithetical and contradictory. It was rather these disparate ethnic groups that the colonial overlords forcefully hammered into one geopolitical amalgam as Nigeria.
\end{abstract}

It is worthy of mention that before the amalgamation, Nigeria was divided into the Southern and Northern protectorates for easy administration. Then in 1914 the two protectorates were amalgamated to form the country known as Nigeria under Lord Fredrick Lugard. According to Uka (2008:3) "Since this geographical expression known as Nigeria was forcefully put together by a foreign power, its disparate units... live in mutual suspicion".

Another contributory factor to ethno-religious conflicts was that British colonial government protected the North from Christian proselytizing influences. Ibenwa and Ngele (2010:127) underscored this point by saying that "the emirs entered into a serious agreement with Lord Lugard that no Christian will be allowed to evangelize the North and that in the event of any "crusade or public preaching" they must get permission from them to do so". This restricted the Church Missionary Society and other Christian missionaries from penetrating the northern part of the country. This undue privilege given to Muslim North could be said to be the beginning of distrust and unhealthy relationship among the religious and ethnic groups in Nigeria that has led to the ugly trend of ethno-religious conflicts that have ravaged the country for years.

\title{
4. Some Cases of Ethno-religious Conflicts in Nigeria: 1980 to 2017
}

There have been many ethno-religious conflicts in Nigeria ranging from Maitatsine riot to Boko haram insurgence. This work summarizes some of the conflicts that have taken place from 1980 to 2017. Reflecting on cases of ethno- religious conflicts in Nigeria, Adebayo (2010:251) wrote that the 1980 Maitatsine riot in Kano metropolis was said to have claimed 4,177 lives. Quoting Imam (2004) he complained that the Maitatsine uprising of Bullum-Kuttu in Bornu State, 26th - 29th October 1982 claimed four hundred lives with properties worth over 3 million naira destroyed or looted. He further stated that, the Jimeta Maitatsine crisis of 26th February - 5th March 1984 took one thousand and four lives, five thousand, nine hundred, and thirteen families were displaced; while over one hundred people died in the Gombe Maitatsine uproar of 26th - 28th April 1985.

The Kafanchan tumult of March 1987 which started in College of Education over a crusade been organized by Christian students spread to Funtua, Kaduna metropolis, Zaria and environs. In this crisis 25 people died, 61 injured, property valued at $\$ 75$ million damaged. About 47, churches, 
3 mosques, 46 private houses, 19 vehicles and 30 hotels were destroyed (Along 2007). Adebayo (2010) also noted that in 1990, the Muslims opposed the invitation of Reinhard Bonnke, a German Christian preacher to Kano; they were not happy because Ahmed Deedat, a Muslim preacher from South Africa was not allowed to come for the same purpose. The result was crises which took place between 11 and 14, October 1990 leaving over 500 lives lost and hundreds of millions of naira worth of property destroyed.

Other riots includes Zangon-Kataf riot of 1992, Futua 1993, Jos crisis of April 1994. Another riot was also witnessed in Kano in December, 1994 triggered by the beheading of an Igbo Christian known as Gideon Akaluka who was alleged to have desecrated the Koran (Jando 2011). These crises though religious in their connotation had touch of ethnic confrontation in them. Lives lost to such sectarian clashes between 1980 and 1994 were well over 10,000 and property destroyed were enormous (Uka 2008). Kaduna riot in Feb. 28, 2000 over the attempt to implement Sharia law led to the killing of about 300 people within the first two days of the crisis (Jando 2011). September 2001 crisis in Jos left over 1,000 people dead including women and children (Okafor, 2007). In 2001 about 500,000 people were displaced and 250,000 in 2002 after ethnic and religious conflict in Nigeria (Isiramen 2010). There was reprisal attack on the Hausa indigenes in Onitsha, Anambra State leading to loss of lives and properties. On July 26-30, 2009 Boko-Haram Islamic Sect unleashed mayhem in Bauchi, Borno, Kano and Yobe. Over 700 persons were killed; 3,500 persons internally displaced; 1,264 children orphaned over 392 women widowed and several properties destroyed (Ukandu 2011). Jos, Plateau State, 2010 Christmas Eve bombing left many injured. On Christmas Day 2011 bombing in Madalla Niger State left about 50 people dead. January 20, 2012 bomb attacks at Kano left at least 250 persons dead (Okpaga, Ugwu, Eme 2012). In Maiduguri, in August 2013, a Christian student reported an attack by Boko Haram on her university accommodation: the men were murdered; the women separated into Muslim and nonMuslims, and the Christian women systematically raped (Hagg, Aja and Chukwuemeka 2015). Also in Maiduguri, six Christian women were abducted and repeatedly raped by insurgents who claimed this as sexual 'jizya', a tax paid by Christians under Islamic law (Hagg, Aja and Chukwuemeka 2015). The Abduction of over 200 girls from Government Girls Secondary School in Chibok, Bornu State on April 14, 2014 by Boko Haram is still vivid in people's minds. On 9 July, 2016, a female preacher Mrs. Eunice Elisha, the wife of a Redeemed Pastor was hacked to death in Abuja by suspected Muslim fanatics (SaharaReporters 2016). .According to the governor of Borno State, Kashim Shettima, the State has about 50,000 widows as result of Boko haram insurgency with 18,600 orphans in Monguno (Ojo 2016:9). Since 2014 at least 2,000 women and girls have been abducted by Boko haram and many have been forced into sexual slavery (Amnesty international as cited by Sahara Reporters 2015). The recent attack of December 2016 by Fulani herds' men in Southern Kaduna where 808 people and properties worth billions of naira were destroyed is another case of violent conflict in Nigeria (THISDAYLive 2016). This conflict in Southern Kaduna continued in February 2017 with many people killed. Other conflicts have taken place in the country leading to loss of lives and destruction of property and more suffering for women.

\section{Implications of Ethno-religious Conflicts on Nigerian Women}

The fact that Nigeria is saddled with ethno-religious conflicts cannot be overemphasized. However, what is most worrisome is little attention being paid to its effect on women. A study carried out by Alawemo and Muterera (2010) on armed conflicts in Nigeria using Jos , Plateau State, as their reference point notes the vulnerability of women and children in conflict situations. According to them these conflicts have led to extensive destruction of lives and properties. At this juncture, we shall turn to examine the economic, social and political implications of Ethno-religious Conflicts on Nigerian women.

\subsection{Economic Implication}

The economic impact of these conflicts on Nigerian women is severe. Due to persistent trend of ethnic and religious bigotry in Nigeria, many women have lost their lives while many others have 
lost their children and/or their husbands. Many houses and means of lively-hood are destroyed resulting in poverty among many families. Many women who became widowed shoulder the responsibility of supporting their families. They now become heads of families and bread winners. Many are also saddled with the burden of taking care of the injured, those orphaned by the persistent ethno-religious conflicts and the elderly. Worse still, some are displaced and forced to run to another communities. These conflicts have led to the establishment of many internally displaced persons' (IDPs) camps in Nigeria. According to Internal Displacement Monitoring Centre (IDMC), as at April 2015, 1,538,982 internally displaced persons' (IDPs) were recorded in Nigeria mainly as a result of insurgency (Eni and Obaji 2016). Many pregnant women in IDPs camps have their babies in such camps. Some women find it difficult to cope with these challenges. They face human rights abuses of different kinds. Their dependants especially the girls are prone to be forced into early marriage, rape, trafficking or prostitution. This leads to the violation of their rights, it also has implications on girls' development and overall development of the country.

In line with this, many women have lost their jobs making them to be economically dependent on their husbands. For example, the following interviews which are just representatives of what women go through reveal the devastating effect of the ethno-religious conflicts on women:

I was a civil servant in Maiduguri enjoying my job. But when all these conflicts became unbearable and life threatening we decided to relocate down East. My husband was lucky to get a job and relocated first, then I joined him with my children. Up till now I do not have a paid job. It is a very difficult situation. You need to depend on your husband in everything" (Nwosu March 4, 2013).

\section{Another victim explained thus:}

I lived in the Northern part of the country from 1999 till 2008. I lived in Katsina, Kano and Niger where my husband did missionary work. We were in Kaduna during the Sharia crisis. I was expecting a baby. Many people were killed. It was a terrible experience. Many people slept in the forest. Women and children usually suffer because many of them who could not run were usually killed... Who is talking about work. It is somebody who is alive that earns money. Many women are turned to house wives, depending solely on their husband if they have any. While others have relocated, especially people from the South. But I pity other women who have no place to run to or money to start another business (Mrs Olinya 181/1/2013).

This underscores the point that ethno-religious conflicts accentuate poverty among the female gender. It has been observed that women make up $65 \%$ of the population below poverty level in Nigeria as against 35\% of men (Emenalo cited in Onah 2011). Many women in Nigeria have remained in poverty. Poverty prevents women and girls from having the basic necessities of life and could force some of them to engage in trading in sex as a means of survival. This makes them vulnerable to unwanted pregnancy, HIVIAIDS and other sexually transmitted diseases (STDs).

\subsection{Social Implication}

Linked to the above is the social and psychological implication of ethno-religious conflicts on women. Ethno-religious conflicts have left people with horrendous experiences and tales of woes. It leads to mental stress and the disruption of social life. The loss of loved ones and uncertainty about the future traumatizes many women. The case of Mrs. Shettima from Bornu State who lost her husband and three children in 2011 during Boko haram insurgence in Maiduguri (Daily Sun, March 5, 2013: 6) is a case in point. She was left desolate, traumatized and inconsolably despondent. Similarly, Mrs Nwosu (Oral interview 2013) who also resided in but fled Maiduguri lamented the loss of her seven months old pregnancy during the riot that erupted after the killing of Mallam Muhammed Yusuf, the leader of Boko Haram in 2009. According to her, it was a very traumatic and depressing experience she does not like to remember.

More to this is that for some of those children affected by the violence, their education is jeopardized in addition to the trauma they pass through. This has serious consequences on the children as poverty can make them drop out of school thereby contributing to the existing problem of school dropouts in Nigeria. As the British Council/UKaid (2012: v) observes "Nigeria has 10.5 
million children out of school...The figures show wide disparities between States and across communities. $70.8 \%$ of young women aged $20-29$ in the North-West are unable to read or write compared to $9.7 \%$ in the South-East". In her own comment, Miss Bakut (Oral interview 2013) explained that "going to school most of the time in those areas affected by such conflicts is a problem because once the atmosphere is tense, people advice their children not go to school. Girls are more scared because they are easily trapped in the violence. There could also be cases of rape but it is not recorded". This has a negative effect because education transforms one's social life in a positive way. UNFPA (cited in Onah (2011:136) avers that "Educational achievements of women can have ripple effects within the family and across generations". Education is a poverty reduction strategy which can be used to create awareness for women on maternal and infant mortality issues, HIVIAIDS, issues relating to peace and governance within their societies, as well as environmentally sustainable practices (Olukunlen and Olugbenga 2006).

In conflict situations women and girls feel more insecure (UNFPA 2002). Their rights are more often than not violated. For example, 20 ladies lost their lives to Boko haram attack in Maiduguri Bornu State on 23 Nov. 2012 for wearing miniskirts and trousers (http://naijagists.com). This is gender-based violence and violation of Human right of women and girls. These raise serious ethical challenge to the Nigerian Government and general populace.

\subsection{Political Implications}

Violence impacts women and men differently, even in conflict situations (Shamima and Kyoko 2014). According to Parliamentary Assembly (2004) women and men have different access to resources, power and decision before, during and after conflicts. While women are the main victims of conflict, they are often powerless to prevent them, they are excluded from negotiation when it comes to resolution and confined to marginal role in the post-conflict reconstruction and reconciliation efforts. This encourages victimization of women. Thus, conflicts intensify gender inequality. This is also the fate of Nigerian women. In Nigeria the social context of gender-based violence is linked to traditional African patriarchal society that determines the gender power structure (Ifemeje 2012). As Osunyikanmi (2011: 62) rightly observed if women are given equal opportunity they will impact meaningfully on Africa's development agenda, most especially on its political development. "They will not remain passive voters, but active participants in politics".

Political marginalization of women is evident in Nigeria where only $9 \%$ of those who stood for election in Nigeria's April 2011 National Assembly elections were women. Nigeria's, house of Representatives has 360 members. Of these only $25(6.9 \%)$ are women. Only about $4 \%$ local government councillors are women. Women are therefore underrepresented in all political decisionmaking bodies (British Council/UKaid 2012). Under the current regime of President Buhari, only six women were appointed ministers out of 36 ministerial positions namely, Mrs Kemi Adeosunminister of Finance, Aisha Abubakar -minister of state of trade, industry and investment, Aisha Jummai Al-Hasan-minister of women affairs, Hajia Zainab Shamsuna Ahmed-minister of state Budget and National planning, Amina Mohammed-the minister for Environment, and Khadija Abba Ibrahim-minister of state foreign affairs. This continues to perpetuate women subordination and gender inequality which runs across the social strata of Nigerian society. The cumulative effect of all these is that ethno-religious conflicts have led to violation of human rights of women and undue sufferings with the concomitant problems of poverty and penury among our womenfolk. Most significantly, it also leads to gender inequality which translates to economic, social and political marginalization of women in the society.

\section{Recommendations}

Given the above scenario, the following recommendations are made for the government at all levels and all stake holders involved.

1. Religion should be used not abused. Adherents of different religions should imbibe the moral teachings of religions such as love for one another, honesty, neighbourliness, justice, tolerance, peace, unity and sanctity of human life. This will foster peaceful co- 
existence.

2. It is pertinent that women should be allowed to be full actors in the process of peace building and conflict resolution in Nigeria. Nigeria is signatory to the Convention for Elimination of All Forms of Discrimination against Women and this should be put into full implementation. The area of peace building and conflict resolution should be gender sensitive. This is because achieving and maintaining peace in any society requires the participation of both men and women. Therefore, gender mainstreaming is essential in peace building activities in the country. Women should not be kept at the margin in political discourse.

3. Rehabilitation of victims of ethno-religious conflicts with special focus on women is very important. Counselling services should be made available to them to enable them overcome their psychological trauma for proper integration in the society.

4. Amidst these incessant ethno-religious conflicts that have plagued the nation, protection of women and children should be of paramount importance and all the violations of human rights of women and children be addressed with the apt attention it deserves.

5. Perpetuators of violence should be penalized as the law stipulates. This will act as a lesson to future offenders.

6. The issue of Muslim-Christian dialogue should be taken seriously by parties involved. During such dialogue, the issue of freedom of worship as stipulated in the constitution of the Federal Republic of Nigeria should be emphasized. This will bring a lasting peace in the country.

\section{Conclusion}

Ethno-religious conflicts pose a major challenge to Nigerians and Nigerian women in particular. Although much has been said and written about Ethno-religious conflicts in Nigeria, the country has continued to witness series of ethnic crisis and religious bigotry leading to conflicts. This has affected sustainable human development. Many lives have been lost and property worth billions destroyed leaving people destitute and homeless. This paper has attempted to examine the implications of these conflicts with particular reference to women. The paper notes that women and children are more vulnerable in these conflict situations and argues that the major effect of these conflicts on women is that it accentuates poverty among the women folk. Poverty exacerbates gender inequality which manifests in economic, social and political spheres of women's lives.

\section{References}

Adebayo, R.I. (2010) Ethno-Religious Crises and the Challenges of sustainable Development in Nigeria. Journal of Sustainable Development in Africa, 12(4), 213-225

Adejo, A.M. (2002). Ethnic and Communal Violence in a Plural Polity: the Nigerian Experience In Angya Charity (ed) F.S.S. Journal of Faculty of Arts Seminar Series, Markudi: Starix Books.

Alawemo, O. and J.Muterera (2010). The Impact of Armed Conflict on Women: Perspectives from Nigerian Women. OIDA Journal of Sustainable Development Vol.2 (5) 81-86.

British Council/UKaid (2012). Gender in Nigeria Report 2012. Improving the lives of Girls and Women in Nigeria. Issues, Policies Action 2nd Edition.

Daily Sun, March 5, 2013: 6.

Dukor, M. (198). Religion and the Nigerian nationhood. In Momoh, C .S. etal (eds). Nigerian Studies in Religious Tolerance. Vol. 111 pp57-68.

Eni A and Obaji S. (2016) Internal Displacement in Nigeria and the Case for Human Rights Protection of Displaced Persons. Journal of Law, Policy and Globalization, 51, 26-33

Jando S.F. (2011) Contemporary Perception of Boko Haram and other Religious Conflicts in Nigeria. A Seminar Paper presented in the of Religion and Cultural Studies, University of Nigeria Nsukka.

Hauwa T. A. (nd) Conflict prevention and post-conflict peace building in Nigeria: Gender Perspective. Retrieved from http://www.humanyknights.net/pdfs/Conflict_Prevention

Jega, I. (2002). Tackling ethno-religious conflicts in Nigeria. Newsletter of Social Science Academy of Nigeria. September, Vol. 5 No 2 (pp.34-38).

Ifemeje S. C. (2012) Gender-Based Domestic Violence in Nigeria: A Socio-Legal Perspective. Indian Journal of 
Gender Studies, 19(1) 137-148

Isiramen, C .O. (2010) Religious crisis and development in Nigeria. in Isiramen, C .O, Imaekhai F.J. and Igboin B.O. (eds) Religion and the Nigerian Nation: Some topical issues. Ibadan: Enjoy Press \& Books.

Ibenwa, C. \& Ngele, O.K. (2010). Religion, Ethnicity and peaceful co-existence in Nigeria. In O.U. Nnadozie and O.Uzoegbunam (Eds.), (pp.122-143). Issues in peace and Conflict Studies and other Social Sciences. Nigeria : Bel's Books.

Ojo S. (2016). Boko Haram: Borno has 50,000 widows-Shettima. Daily Sun 2016 p9.

Olukunlen, K. F. and Olugbenga, D. O (2006). Distance education as a women empowerment strategy in Africa. Turkish Online Journal of Distance Education TOJDE 7, (1) Article 13.

Onah. N.G. (2011) Women empowerment in 21st century Nigeria: The role of faith-based Organizations. Nigerian Journal of Social Sciences. Vol. 7 (2) 130-141.

Onimhawo, J.A. and Ottuh, P.O.O.(2010). An Exploration of Inter-religious relations in Nigeria: The ChristianMuslim Experience. In (eds) Isiramen C.O., Umujesi, I.O, Ottuh, Falaiye E.A. Issues in Religious Studies and Philosophy. Ibadan: En-joy Press \& Books.

Okafor, E. E. (2007). Sociological Implications of Communal and Ethno-Religious clashes in New Democratic Nigeria. Stud. Tribes Tribals, 5(1): 35-45.

Okpaga, A. Ugwu, S. Eme E. (2012) Activities of Boko Haram and insecurity question in Nigeria. Arabian Journal of Business and Management Review (OMAN Chapter) Vol. 1, (.9) 77-98.

Parliamentary Assembly (2004) Conflict Prevention and Reconciliation: the role of women. Accessed on 13 October 2016 from http://assembly.coe.int/nw/xml/XRef/Xref-XML2HTML-en.asp?fileid=17233\&lang=en

Osunyikanmi, A.F. (2011) The Political Implications of Violence Against Women in Africa. Canadian Social Science Vol. 7, (5) 58-63.

SaharaReporters (2016) How Suspected Muslim Fanatics Hacked Female Redeemed Church Preacher to Death in Abuja. Accessed on 13October from http://saharareporters.com/2016/07/11/how-suspectedmuslim-fanatics-hacked-female-redeemed-church-preacher-death-abuja

SaharaReporters (2016) Abducted Women and Girls Forced to Join Boko Haram Attacks, Amnesty International Reports accessed on 13October 2016 from http://saharareporters.com/2015/04/14/abducted-women-andgirls-forced-join-boko-haram-attacks-amnesty-international-reports

Shamima A. and Kyoko K. (2014). Gender-based Violence among Documented Rohingya Refugees in Bangladesh. Indian Journal of Gender Studies, 21, 2 (2014): 225-246

THISDAYLive (2016) 808 Killed in Southern Kaduna Attacks, Says Catholic Church. http://www.thisdaylive.com/index.php/2016/12/30/808-killed-in-southern-kaduna-attacks-says-catholicchurch/ Accessed 13 February 2017.

Uchendu E. (2010) Religious Conflicts in Nigeria: Implications on Socio-Economic and Psychological Perceptions of Muslims in Igbo Land. Retrieved from http://www.egodiuchendu.com/index.php?option=com content\&view=article\&id=66:-

Uka E.M., (2008). Ethnic, Religious and Communal Conflict in Nigeria: Implication for Security. Professor Bassey Andah Journal of Cultural Studies. (1)1-17.

Ukandu, I.K. (2011) Boko Haram and National Security in Nigeria: The Imperative of Religious Peacemaking. A Seminar Paper presented in the of Religion and Cultural Studies, University of Nigeria Nsukka.

UNFPA (2002). The Impact of Conflict on Women and Girls: A UNFPA Strategy for Gender Mainstreaming in Areas of Conflict and Reconstruction. Bratislava, Slovakia.

World population Review (2016) Nigeria Population 2016. Accessed on $4^{\text {th }}$ October 2016 from http://worldpopulationreview.com/countries/nigeria-population/

Yusuf A.R. and Osoba A.J. (2010). The growth of Christianity in Lagos State. Growth and Development Retrieved from http://cefolassaocoed.net/index.php?

Yakubu J. \& Rothfuss R., (2012). Threats to Religious freedom in Nigeria. International of Religious freedom. 5(1) pp 73-85. 